\title{
Role of the bacterial community in the annual benthic metabolism of two contrasted temperate intertidal sites (Roscoff Aber Bay, France)
}

\author{
Cédric Hubas ${ }^{1,2, *}$, Luis Felipe Artigas ${ }^{1}$, Dominique Davoult ${ }^{2}$ \\ ${ }^{1}$ FRE 2816 ELICO, Université du Littoral Côte d'Opale, Maison de la Recherche en Environnement Naturel, 32 av. Foch, \\ Wimereux 62930, France \\ ${ }^{2}$ UMR 7144 AD2M, Université Pierre et Marie Curie-Paris 6, Station Biologique de Roscoff, BP 74, Roscoff 29680, France
}

\begin{abstract}
The role of the bacterial community in the annual benthic metabolism of Roscoff Aber Bay, France, was estimated during low tide at 2 sampling sites of different trophic status, located at either end of a strong environmental gradient. The benthic gross primary production (GPP) and community respiration (BCR) were assessed in situ over 1 yr with a benthic chamber; simultaneously, bacterial production (BP) was estimated by radiotracer incorporation in slurries. BP appeared to be significantly controlled by temperature during low tide. On an annual scale, microphytobenthos gross primary production $\left(\mathrm{GPP}_{\mathrm{a}}\right)$, bacterial production $\left(\mathrm{BP}_{\mathrm{a}}\right)$, meiofauna production $\left(\mathrm{MeP}_{\mathrm{a}}\right)$, macrofauna production $\left(\mathrm{MaP}_{\mathrm{a}}\right)$ and benthic community respiration $\left(\mathrm{BCR}_{\mathrm{a}}\right)$ were estimated. While the estimated annual processes were generally higher at the muddy station, our results indicated that (1) the contribution of $\mathrm{BP}_{\mathrm{a}}$ to the annual benthic community production $\left(\mathrm{CP}_{\mathrm{a}}=\mathrm{BP}_{\mathrm{a}}+\mathrm{MeP}_{\mathrm{a}}+\mathrm{MaP}_{\mathrm{a}}\right)$ increased with increasing grain size, and (2) the bacterial community can modulate its growth efficiency $\left(\mathrm{BGE}_{\mathrm{a}}\right)$ when exposed to an environmental gradient: in intertidal sediments, the production of new cells is enhanced when the organic matter concentration is lower, sustaining the development of the community on the annual scale. This behaviour was inferred to be the predominant factor affecting the trophic state of the system.
\end{abstract}

KEY WORDS: Intertidal sediments · Benthic bacterial growth efficiency · Gross primary production · Community respiration

Resale or republication not permitted without written consent of the publisher

\section{INTRODUCTION}

In aquatic ecosystems, organic carbon is mainly processed by bacterial communities (Cole 1999). The carbon processed can be distributed either into the anabolic (i.e. transformed into particulate carbon by the bacterial production, BP) or the catabolic pathway (i.e. re-mineralized by the bacterial respiration, BR). The relative magnitudes of $\mathrm{BR}$ and $\mathrm{BP}$ are controlled by the bacterial growth efficiency $(B G E=[B P / B P+B R])$, which represents the fraction of assimilated organic carbon that supports bacterial growth and, therefore, is immediately available to higher trophic levels (del Giorgio \& Cole 1998). Over the past decades, the simultaneous measurements of these 2 processes have been of increasing interest, improving our understanding of the carbon cycle in aquatic ecosystems (Jahnke \& Craven 1995, del Giorgio \& Williams 2005), but to date very few studies have dealt with accurate estimations of BR rates. While there is still no consensus on what primarily drives the great BGE variability (Roland \& Cole 1999), it is now well accepted that even if the BGE is variable, the respiration is generally higher than the production (i.e. BGE ranges from 15 to $30 \%$ in a wide range of aquatic ecosystems, del Giorgio \& Cole 1998, 2000). BGE is thus very low in marine ecosystems $(<30 \%$, including estuaries).

This topic has been well studied in pelagic ecosystems (del Giorgio \& Cole 2000). However, although the ecology of micro-benthos has been studied over a 
number of decades (Fenchel 1978), BGE has been comparatively seldom studied in benthic ecosystems, particularly in intertidal ecosystems, which play an important role in the production and re-mineralization of organic matter. Indeed, relatively little is known about BP in marine sediments (Sander \& Kalff 1993), and even less is known about BR rates. In intertidal soft sediments, primary production is (1) generally very important because the sediments are characterized by long emersion periods and high irradiance levels, and (2) dominated by benthic microalgae (McIntyre et al. 1996). Moreover, bacterial production and re-mineralization represent the main fate of the primary production in these ecosystems (Ducklow 1999, Middelburg et al. 2000).

In the present study, benthic gross primary production (GPP) and benthic community respiration (BCR) were measured in situ on emersed soft sediments within a benthic chamber in a macrotidal temperate bay. These measurements were simultaneously assessed with benthic BP, biomass (BB) and chlorophyll a (chl a) concentration. The aim of this study was to (1) assess the temporal variability of the benthic primary and bacterial production, and (2) study and compare the annual benthic primary production and BGE in 2 contrasted intertidal sediments located at either end of a strong environmental gradient.

\section{MATERIALS AND METHODS}

Sampling area. Roscoff Aber Bay, France (Fig. 1; $\sim 2 \mathrm{~km}$ long, $1 \mathrm{~km}$ wide) is entirely located above midtide level (Chauris 1988). Two sampling sites were studied during low tide from March 2005 to February 2006: the 'river station' (Stn A: $48^{\circ} 42.82^{\prime} \mathrm{N}$, $4^{\circ} 00.05^{\prime} \mathrm{W}$ ) located at the river entrance, and the 'Roch Kroum station' (Stn C: $48^{\circ} 43.44^{\prime}$ N, $3^{\circ} 59.77^{\prime}$ W). Stn A was characterized by very fine sand sediments (median grain size $=132 \pm 54 \mu \mathrm{m})$, and Stn $\mathrm{C}$ by medium sand sediment $(251 \pm 10 \mu \mathrm{m})$.

Chl a concentration. The top $2 \mathrm{~mm}$ of sediment were sampled during emersion (triplicates with a $1.6 \mathrm{~cm}$ inner diameter cut-off syringe). Samples were then stored in a cool box until their return to the laboratory and stored at $-20^{\circ} \mathrm{C}$ until analysis. Sediment cores were defrosted in the dark, and chl a extraction was performed with $90 \%$ acetone (Strickland \& Parsons 1972). All samples were centrifuged $(800 \times g, 3 \mathrm{~min})$. Supernatants were removed and chl a concentration was measured by fluorimetry (Yentsch \& Menzel 1963). Chl a concentration was then calculated according to Lorenzen (1966).

Bacterial biomass. BB was estimated from $1.6 \mathrm{~cm}$ inner diameter $(1 \mathrm{~cm}$ depth) cores collected with a cut-off alcohol-cleaned syringe (triplicates) during low tide. Samples were immediately fixed in $20 \mathrm{ml}$ boratebuffered $0.2 \mu \mathrm{m}$ pre-filtered formalin (3\% final concentration). Bacterial communities were then extracted from sediment by addition of $150 \mu \mathrm{l}$ Tween 80 (Chevaldonné \& Godfroy 1997), followed by sonication (35 kHz, $5 \mathrm{~min})$ and centrifugation $\left(1750 \times g, 10 \mathrm{~min}, 4^{\circ} \mathrm{C}\right)$. Samples were stained with DAPI $\left(2 \mu \mathrm{g} \mathrm{ml}^{-1}\right)$ for $15 \mathrm{~min}$ (Porter \& Feig 1980) and counted by epifluorescence microscopy. Carbon biomass was estimated assuming $20 \mathrm{fg} \mathrm{C}$ cell $^{-1}$ (Lee \& Fuhrman 1987, Cho \& Azam 1990, Delmas et al. 1992, Raghukumar et al. 2001).

Gross primary production and benthic community respiration. Benthic metabolism was regularly measured from March 2005 to February 2006 in situ during low tide within a benthic chamber (Migné et al. 2002). Briefly, a $0.071 \mathrm{~m}^{2}$ sediment area was enclosed using a Perspex dome fitted onto a stainless-steel ring and pushed into the emersed sediment to about $10 \mathrm{~cm}$
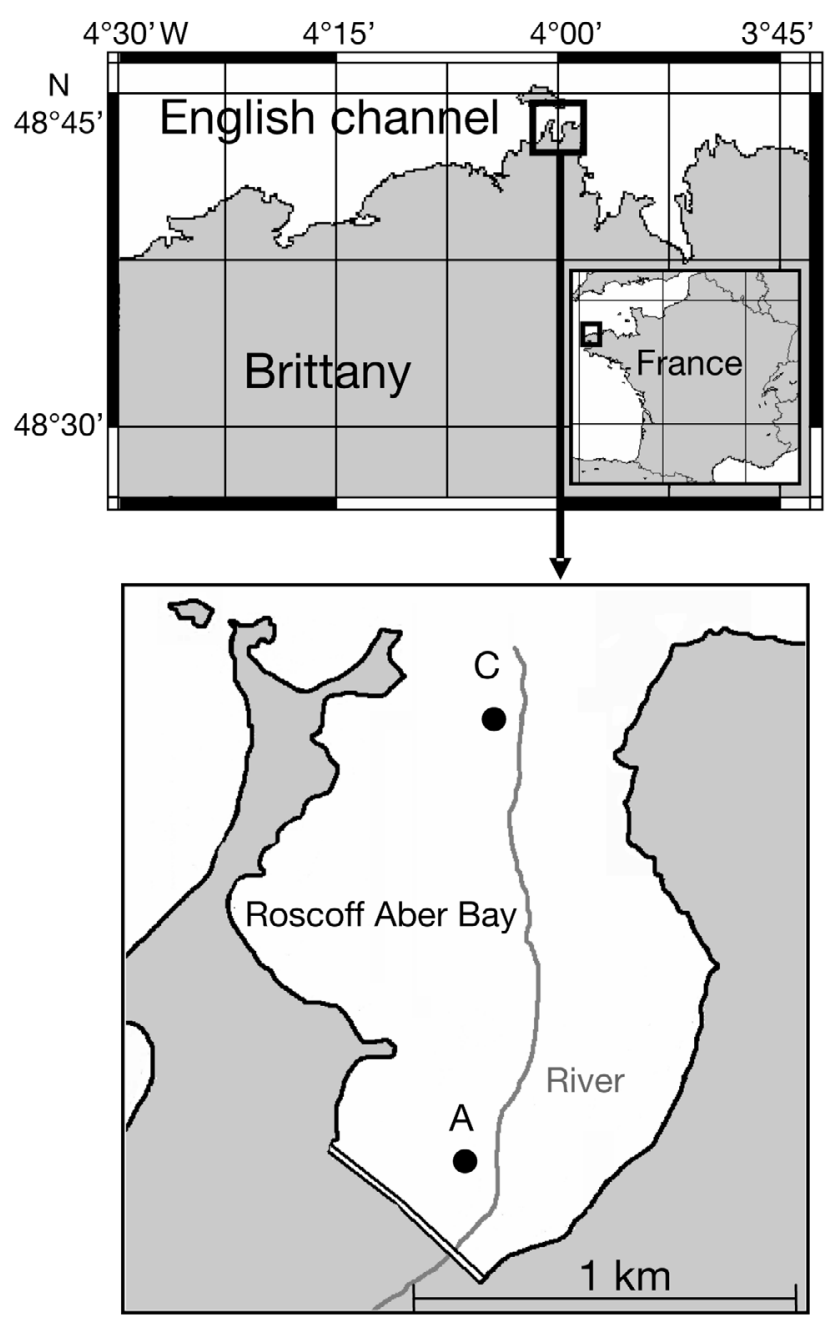

Fig. 1. Location of sampling stations (Stns A and C) in Roscoff Aber Bay, France 
depth. The benthic chamber was connected to a closed circuit of $\mathrm{CO}_{2}$ analysis. Gas exchange was monitored with an infrared $\mathrm{CO}_{2}$ gas analyzer (LiCor Li 800) at the air-sediment interface. Partial pressure of $\mathrm{CO}_{2}$ was then regressed against time, from recorded data of both light and dark incubation. Results were expressed in carbon units for the bulk benthic community (mgC $\mathrm{m}^{-2} \mathrm{~h}^{-1}$ ). Benthic GPP was then calculated from benthic net primary production (NPP) and BCR measurements $(\mathrm{GPP}=\mathrm{NPP}+\mathrm{BCR})$. Incident photosynthetically active radiation (400 to $700 \mathrm{~nm}, \mathrm{PAR}$ in $\mu \mathrm{mol}$ quanta $\mathrm{m}^{-2} \mathrm{~s}^{-1}$ ) was also measured inside the benthic chamber with a LiCor quantum sensor. Data were recorded with a data logger (LiCor Li-1400) with a 30 s logging frequency. Light and dark incubations were assessed between 20 and $90 \mathrm{~min}$, depending on the response of the sediment, in order to encompass the buffering effect of the carbonate system in the pore water of the sediment.

Bacterial production. Bacterial carbon production was estimated by [methyl- $\left.{ }^{3} \mathrm{H}\right]$ thymidine (specific activity, $\mathrm{SA}, 48$ to $54 \mathrm{Ci} \mathrm{mmol}^{-1}$ ) incorporation rate (Fuhrman \& Azam 1982). Sediment cores (triplicates with a $1.6 \mathrm{~cm}$ inner diameter cut-off syringe, $1 \mathrm{~cm}$ depth) were sampled (March 2005 to February 2006) during emersion at the end of the benthic chamber incubation period. Sediment slurries were incubated with [methyl- ${ }^{3} \mathrm{H}$ ] thymidine (final concentration 300 $\mathrm{nM}$ ) for $20 \mathrm{~min}$. The appropriate concentration (Moriarty 1986) and the linearity of the incorporation over time were verified in preliminary experiments for each type of sediment. The samples were then filtered $(0.2 \mu \mathrm{m})$ and rinsed with $80 \%$ ethanol and $5 \%$ trichloroacetic acid (TCA). The filters were mixed with $5 \mathrm{ml} 0.5 \mathrm{M} \mathrm{HCl}$ and incubated at $95^{\circ} \mathrm{C}$ for $16 \mathrm{~h}$ (Garet \& Moriarty 1996). The supernatant was cooled and mixed with $3 \mathrm{ml}$ of the scintillation cocktail Ultima Gold MV. Bacterial production was calculated assuming $2 \times 10^{18}$ cells mol ${ }^{-1}$ incorporated thymidine (Moriarty 1986, Bell 1993) and $20 \mathrm{fg} \mathrm{C}$ cell $^{-1}$ (Lee \& Fuhrman 1987, Cho \& Azam 1990, Delmas et al. 1992, Raghukumar et al. 2001). Daily BP was simply estimated by integrating BP data over $24 \mathrm{~h}$.

Temperature influence. The influence of sediment temperature on benthic BP was tested with an exponential curve (Arrhenius plot) according to Hancke \& Glud (2004) using the SPSS Systat 9 software:

$$
\mathrm{BP}=A_{\mathrm{i}} \times \exp \left(-E_{\mathrm{ai}} \times R T^{-1}\right)
$$

where BP is expressed in $\mathrm{mg} \mathrm{C} \mathrm{m} \mathrm{m}^{-2} \mathrm{~h}^{-1}, A_{\mathrm{i}}$ is a preexponential factor, $E_{\mathrm{ai}}$ was the community response of $\mathrm{BP}$ to temperature (apparent activation energy, $\mathrm{J}$ $\left.\mathrm{mol}^{-1}\right), R$ was the gas constant $\left(8.3144 \mathrm{~J} \mathrm{~K}^{-1} \mathrm{~mol}^{-1}\right)$ and $T$ the sediment temperature $(\mathrm{K}) . Q_{10}$ values were calculated from the non-linear regressions of Eq. (1) using the ratio between $\mathrm{BP}$ at $T$ and $\mathrm{BP}$ at $T+10 \mathrm{~K}$ :

$$
Q_{10}=\mathrm{BP}_{T} / \mathrm{BP}_{T+10 \mathrm{~K}}
$$

Temperature was also artificially modified in the laboratory and its influence on benthic BP tested. Because BP plotted against temperature expresses a classical metabolic-temperature response (i.e. an increase in GPP until temperature reaches an optimum, followed by a decrease), a short-term temperature-influence model (Blanchard et al. 1996, cardinal temperature model) was fitted to BP at this sampling site using Statsoft Statistica version 6.1.:

$$
\mathrm{BP}=\mathrm{BP}_{\max }\left(\frac{T_{\max }-T}{T_{\max }-T_{\mathrm{opt}}}\right)^{\beta} \exp \left[-\beta\left(\frac{T_{\max }-T}{T_{\max }-T_{\mathrm{opt}}}-1\right)\right]
$$

where $\mathrm{BP}_{\max }$ represents maximum $\mathrm{BP}, \mathrm{T}$ is temperature $\left({ }^{\circ} \mathrm{C}\right), T_{\text {opt }}$ is optimal temperature (i.e. corresponding to the maximum $\mathrm{BP}), T_{\max }$ is the maximum temperature that is tolerated by the bacterial community (i.e. beyond $T_{\text {opt }}$ BP decreases and reaches zero at $T_{\max }$ ), and $\beta$ is a dimensionless adjustment parameter. The following cardinal temperature criteria were used for categorization: psychrophiles $T_{\text {opt }} \leq 15^{\circ} \mathrm{C}$ and $T_{\text {max }} \leq$ $35^{\circ} \mathrm{C}$, psychrotrophs $T_{\text {opt }} \leq 25^{\circ} \mathrm{C}$ and $T_{\text {max }} \leq 35^{\circ} \mathrm{C}$, and mesophiles $T_{\text {opt }} \approx 25$ to $40^{\circ} \mathrm{C}$ and $T_{\text {max }} \approx 35$ to $45^{\circ} \mathrm{C}$ (Isaksen \& Jørgensen 1996, Hancke \& Glud 2004).

Annual gross primary production. The determination of annual benthic gross primary production $\left(\mathrm{GPP}_{\mathrm{a}}\right)$ is detailed elsewhere (Migné et al. 2004, Hubas \& Davoult 2006, Spilmont et al. 2006). Briefly, the relationship between GPP and light intensity was established at Stn A from field measurements made within the benthic chamber in a previous study (Hubas \& Davoult 2006). NPP was measured in ambient light from sunrise to saturating light, and BCR was measured in darkness. GPP was calculated from NPP and BCR measurements and plotted against light intensity. Photosynthetic parameters $\left(\mathrm{GPP}_{\max }\right.$ and the saturation onset parameter $I_{\mathrm{k}}$ ) were estimated by fitting the data with the mathematical model of Webb et al. (1974):

$$
\mathrm{GPP}=\mathrm{GPP}_{\max }\left[1-\exp \left(-I / I_{\mathrm{k}}\right)\right]
$$

where GPP is expressed in $\mathrm{mg} \mathrm{C} \mathrm{m}^{-2} \mathrm{~h}^{-1}, \mathrm{GPP}_{\max }$ is the rate of maximum GPP, and $I$ is the incident light intensity ( $\mu$ mol quanta $\mathrm{m}^{-2} \mathrm{~s}^{-1}$ ).

Each photosynthetic parameter $\left(\mathrm{GPP}_{\max }\right.$ and $\left.I_{\mathrm{k}}\right)$ was plotted against time (d) and fitted with a sinusoidal curve. The fitted curves were used to express daily $\mathrm{GPP}_{\max }$ as a function of irradiance. GPP $\mathrm{G}_{\mathrm{a}}$ was then estimated by taking into consideration (1) the fact that GPP was light-limited during high tide and restricted to the emersion period, and (2) the day/ night cycle. The irradiance was measured every $1 \mathrm{~min}$ and recorded every $15 \mathrm{~min}$ at a station close to the study site. 
Annual macrofauna and meiofauna secondary production. The secondary production of meiofauna and macrofauna was estimated from biomass measurements made regularly between February 2003 and February 2004 at Stns A and C (Hubas et al. 2006). For meiofauna, secondary production was estimated using a production-to-biomass ratio (P:B ratio) that ranged from 9 to $15 \mathrm{yr}^{-1}$ (Gerlach 1971, Raffaelli \& Hawkins 1999). Similarly, for macrofauna, secondary production was estimated using a P:B ratio that ranged from 0.5 to $3 \mathrm{yr}^{-1}$ (Koop \& Griffiths 1982, Raffaelli \& Hawkins 1999) and a conversion factor of $0.4 \mathrm{~g} \mathrm{C} \mathrm{g}^{-1}$ ash-free dry weight (AFDW) (Steele 1974).

Annual bacterial growth efficiency. The annual bacterial growth efficiency $\left(\mathrm{BGE}_{\mathrm{a}}\right)$ would represent the amount of bacterial biomass synthesized in $1 \mathrm{yr}$ per unit of substrate processed $\left(\mathrm{BGE}_{\mathrm{a}}=\mathrm{BP}_{\mathrm{a}} / \mathrm{BCD}_{\mathrm{a}}\right.$ i del Giorgio \& Cole 1998, 2000). BCD ${ }_{a}$ represents the annual bacterial carbon demand $\left(\mathrm{BCD}_{\mathrm{a}}=\mathrm{BP}_{\mathrm{a}}+\mathrm{BR}_{\mathrm{a}}\right)$, and $\mathrm{BP}_{\mathrm{a}}$ and $\mathrm{BR}_{\mathrm{a}}$ represent the annual bacterial production and respiration, respectively. The latter parameter was not measured in the present study. The $\mathrm{BGE}_{\mathrm{a}}$ was thus initially calculated by assuming that the respiration of the bacterial component $\left(\mathrm{BR}_{\mathrm{a}}\right)$ represented $0 \%$ of the annual benthic community respiration $\left(\mathrm{BCR}_{\mathrm{a}}\right.$, measured in the benthic chamber and including both auto- and heterotrophic respiration). This percentage was increased gradually to $100 \%$, and $\mathrm{BGE}_{\mathrm{a}}$ calculated with each incremental increase ( $10 \%$ each time). The $\mathrm{BGE}_{\mathrm{a}}$ of the 2 sampling sites were then compared.

\section{RESULTS}

\section{Chl a concentration and bacterial biomass}

Chl a ranged from 37 to 83 and from 18 to $39 \mathrm{mg} \mathrm{chl} \mathrm{a}$ $\mathrm{m}^{-2}$ at Stns A and C, respectively (Fig. 2). Statistical analysis revealed significant differences in chl a between sampling sites (Mann-Whitney $U$-test, p < 0.01). Chl a concentration was higher at Stn A (67 \pm

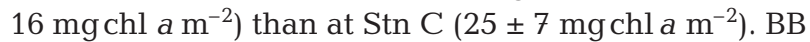
ranged from 10 to 49 and 5 to $21 \mathrm{mgC} \mathrm{m}^{-2}$ at Stns A and $\mathrm{C}$, respectively (Fig. 2). Biomass values measured in this study were similar to those previously reported for Roscoff Aber Bay (Hubas et al. 2006), and were within the range of the values reported in the literature for intertidal mud- and sandflats (Lucas et al. 1996, Epstein 1997, Goñi-Urriza et al. 1999, Böttcher et al. 2000, Danovaro et al. 2001). At Stns A and C, both chl $a$ and BB showed seasonal variation, but neither were coupled to primary production or BP (Pearson's correlation, $\mathrm{p}>0.05)$.

\section{Benthic metabolism}

On average, BCR rates were significantly different between Stns A and C (Mann-Whitney $U$-test, p < 0.01) and ranged from 1 to 9 and 0 to $3 \mathrm{mgC} \mathrm{m}^{-2} \mathrm{~h}^{-1}$ at Stns $\mathrm{A}$ and $\mathrm{C}$, respectively. $\mathrm{BCR}\left(\mathrm{mg} \mathrm{C} \mathrm{m}^{-2} \mathrm{~h}^{-1}\right)$ exhibited a seasonal pattern (Fig. 3) and was fitted with a sinusoidal curve using Systat 9:

Stn A: BCR $=3.687-2.608 \sin [(2 \pi / 365) d+0.458]$

$$
\left(\mathrm{R}^{2}=0.90, \mathrm{n}=10, \mathrm{p}<0.001\right)
$$

Stn $\mathrm{C}: \mathrm{BCR}=0.881-0.880 \sin [(2 \pi / 365) d+0.632]$

$$
\left(R^{2}=0.78, n=9, p<0.01\right)
$$

where $d$ represents time in days. According to the regression, maximum $\mathrm{BCR}$ was achieved in summer at Stn A (Day 247, beginning of September, $6.3 \mathrm{mgC}$ $\mathrm{m}^{-2} \mathrm{~h}^{-1}$ ) and Stn C (Day 237, end of August, $1.8 \mathrm{mgC}$ $\mathrm{m}^{-2} \mathrm{~h}^{-1}$ ).

On average, BP rates did not differ significantly between Stns A and C (Mann-Whitney $U$-test, p > 0.05)

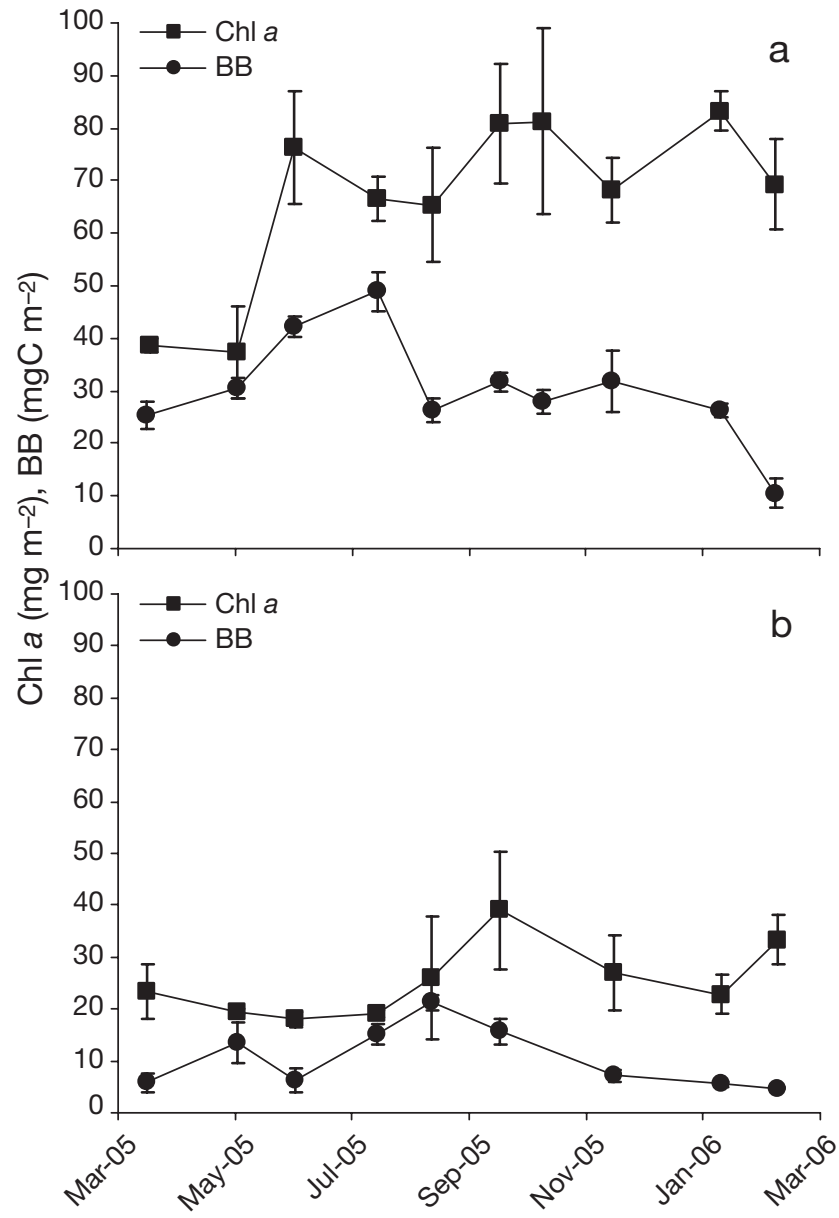

Fig. 2. Chl a concentration and bacterial biomass (BB) measured at (a) Stn A and (b) Stn C between March 2005 and February 2006 
and ranged from 1 to 4 and 0 to $3 \mathrm{mgC} \mathrm{m}^{-2} \mathrm{~h}^{-1}$ at Stns A and $\mathrm{C}$, respectively. BP $\left(\mathrm{mg} \mathrm{C} \mathrm{m}^{-2} \mathrm{~h}^{-1}\right)$ also exhibited a seasonal pattern (Fig. 3) and was fitted with a sinusoidal curve

$$
\begin{gathered}
\text { Stn } \mathrm{A}: \mathrm{BP}=2.147-1.160 \sin [(2 \pi / 365) d+0.646] \\
\left(\mathrm{R}^{2}=0.89, \mathrm{n}=10, \mathrm{p}<0.001\right)
\end{gathered}
$$

Stn $\mathrm{C}: \mathrm{BP}=1.155-1.154 \sin [(2 \pi / 365) d+0.599]$

$$
\left(\mathrm{R}^{2}=0.85, \mathrm{n}=9, \mathrm{p}<0.01\right)
$$

Maximum BP was achieved in summer at Stn A (Day 236, end of August, $3.3 \mathrm{mg} \mathrm{C} \mathrm{m}^{-2} \mathrm{~h}^{-1}$ ) Stn and C (Day 239, end of August, $2.3 \mathrm{mg} \mathrm{C} \mathrm{m}^{-2} \mathrm{~h}^{-1}$ ). GPP also exhibited a seasonal pattern (Fig. 3). However, GPP data were not fitted with a sinusoidal curve since the non-linear regression was not further used. On average, GPP rates were also significantly different between Stns A and C (MannWhitney $U$-test, $\mathrm{p}<0.01$ ) and ranged from 11 to 33 and 5 to $12 \mathrm{mg} \mathrm{C} \mathrm{m}^{-2} \mathrm{~h}^{-1}$ at Stns A and C, respectively.

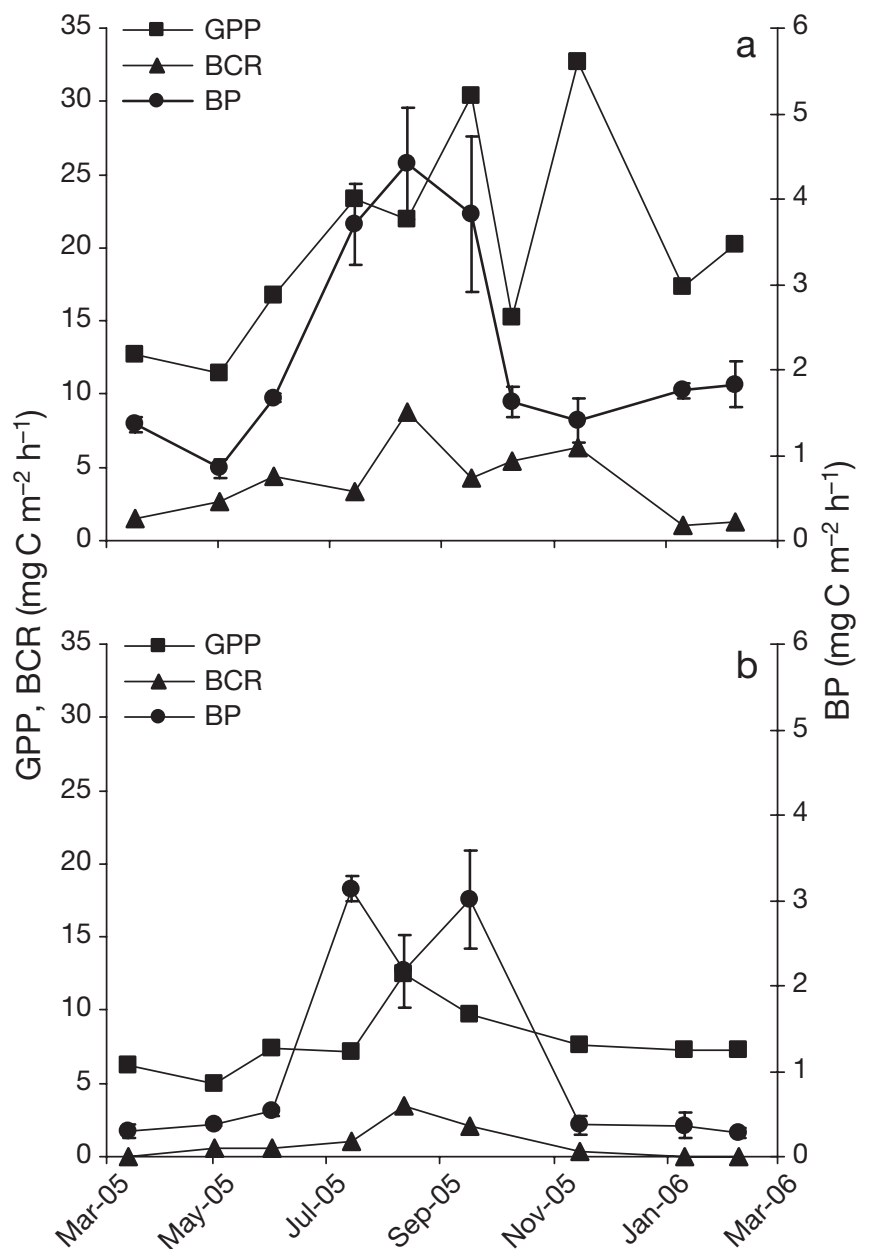

Fig. 3. Gross primary production (GPP), benthic community respiration (BCR) and bacterial production (BP) measured at (a) Stn A and (b) Stn C between March 2005 and February 2006

\section{Temperature influence}

The effect of in situ sediment temperature on BP was tested at Stns A and $\mathrm{C}$ with an exponential curve. At these stations, temperature appeared to significantly control BP (Fig. 4a,c): temperature coefficients $\left(Q_{10}\right)$ indicated an increase in $\mathrm{BP}$ rates for a $10^{\circ} \mathrm{C}$ rise in temperature (Table 1). Moreover, in May 2005, BP was measured in the laboratory under an increasing temperature gradient $\left(5,11,16,22,27\right.$ and $\left.32^{\circ} \mathrm{C}\right)$ in order to evaluate the effect of an excessive temperature increase on BP (Fig. 4b,d). When plotted against $T^{\circ} \mathrm{C}$, BP exhibited a classical metabolic-temperature response at Stn A (i.e. an increase in BP up until an optimal $T^{\circ} \mathrm{C}$, followed by a decrease). The effect of the temperature increase on BP was thus tested with a cardinal temperature model. The optimal temperature for $\mathrm{BP}$ at Stn A was $27.4^{\circ} \mathrm{C}$. It was not possible to fit the cardinal temperature model at Stn $\mathrm{C}$.

\section{Annual production}

The day-to-day variation in GPP was calculated from in situ measurements made previously at the same sampling sites (Hubas \& Davoult 2006). GPP ${ }_{a}$ was determined from the GPP of each day of the year. The $\mathrm{GPP}_{\mathrm{a}}$ was higher at Stn A $\left(28.8 \mathrm{gC} \mathrm{m}^{-2} \mathrm{yr}^{-1}\right)$ than at Stn C $\left(6.7 \mathrm{~g} \mathrm{C} \mathrm{m}^{-2} \mathrm{yr}^{-1}\right)$. The day-to-day variations in $\mathrm{BCR}$ and $\mathrm{BP}$ were estimated by simply multiplying the values of the sinusoidal curves fitted on the hourly rates by $24 \mathrm{~h}$ (Fig. 3). $\mathrm{BCR}_{\mathrm{a}}$ and $\mathrm{BP}_{\mathrm{a}}$ were calculated as described above for $\mathrm{GPP}_{\mathrm{a}}$. The $\mathrm{BCR}_{\mathrm{a}}$ followed the sedimentary gradient, being higher at $\operatorname{Stn} \mathrm{A}\left(51.3 \mathrm{~g} \mathrm{C} \mathrm{m}^{-2}\right.$ $\left.\mathrm{yr}^{-1}\right)$ than at $\mathrm{Stn} \mathrm{C}\left(4.3 \mathrm{gC} \mathrm{m}^{-2} \mathrm{yr}^{-1}\right) . \mathrm{BP}_{\mathrm{a}}$ was also higher at Stn $\mathrm{A}\left(18.8 \mathrm{gC} \mathrm{m}^{-2} \mathrm{yr}^{-1}\right)$ than at Stn $\mathrm{C}$ $\left(10.1 \mathrm{~g} \mathrm{C} \mathrm{m}^{-2} \mathrm{yr}^{-1}\right)$. For meiofauna, the average biomass was $1.99 \pm 0.42$ and $0.47 \pm 0.24 \mathrm{~g} \mathrm{C} \mathrm{m}^{-2}$ at Stns A and $\mathrm{C}$, respectively. Depending on the P:B ratio utilized, the annual meiofauna production $\left(\mathrm{MeP}_{\mathrm{a}}\right)$ thus varied between 17.9 and 29.8 and between 4.3 and $7.1 \mathrm{~g} \mathrm{C} \mathrm{m}^{-2}$ $\mathrm{yr}^{-1}$ at Stns A and C, respectively. Similarly, for macrofauna, average biomass was $18.61 \pm 6.13$ and $1.57 \pm$

Table 1. Bacterial production (BP) temperature response curve parameters calculated from non-linear regression using the Arrhenius plot. $A_{\mathrm{i}}$ : pre-exponential factor; $E_{\mathrm{ai}}$ : apparent activation energy $\left(\mathrm{kJ} \mathrm{mol}^{-1}\right)_{i} \mathrm{R}^{2}$ : coefficient of determination; $\mathrm{n}$ : no. of couple values (n); $Q_{10}$ : metabolism response to a $10^{\circ} \mathrm{C}$ rise in temperature ${ }^{* * *} p<0.001 i^{* *} p<0.01$

\begin{tabular}{|lccccc|}
\hline Stn & $A_{\mathrm{i}}$ & $E_{\mathrm{ai}}$ & $\mathrm{R}^{2}$ & $\mathrm{n}$ & $Q_{10}$ \\
\hline $\mathrm{A}$ & $4.6 \times 10^{8}$ & 461.5 & $0.94^{* * *}$ & 8 & 2.0 \\
$\mathrm{C}$ & $3.7 \times 10^{16}$ & 917.3 & $0.78^{* *}$ & 8 & 3.8 \\
\hline
\end{tabular}



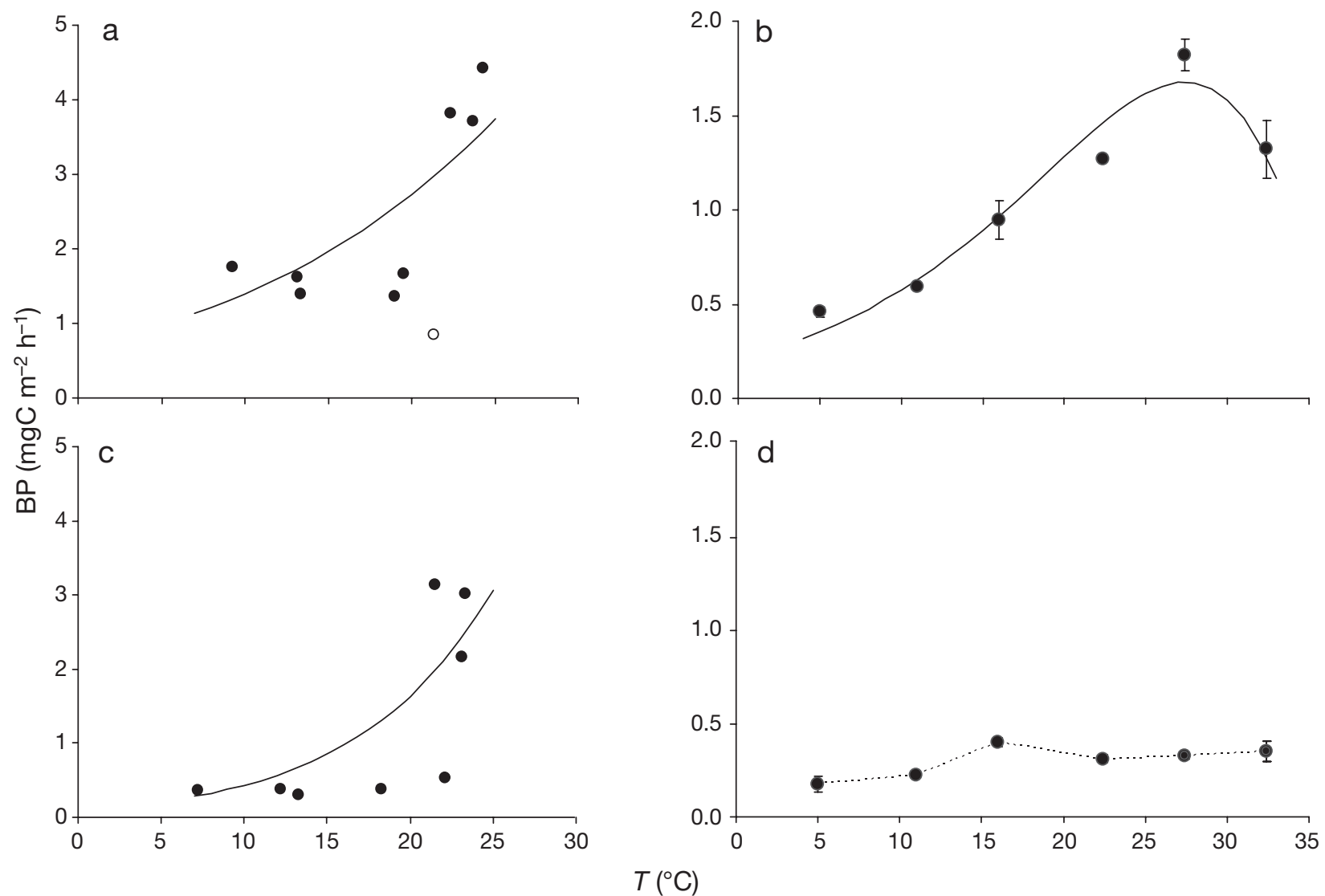

Fig. 4. BP temperature response curves at Stns A and C using $(\mathrm{a}, \mathrm{c})$ the Arrhenius plot and $(\mathrm{b}, \mathrm{d})$ cardinal temperature criteria. $\mathrm{O}$ : data that did not fit the non-linear regression

$0.72 \mathrm{~g} \mathrm{AFDW} \mathrm{m}^{-2}$ at Stns A and C, respectively. Consequently, the annual macrofauna production $\left(\mathrm{MaP}_{\mathrm{a}}\right)$ varied between 3.7 and 22.3 and between 0.3 and $1.9 \mathrm{~g} \mathrm{C} \mathrm{m}^{-2} \mathrm{yr}^{-1}$ at Stns A and C, respectively. These rates are summarized in Table 2 . The total benthic community production $\left(\mathrm{CP}_{\mathrm{a}}=\mathrm{MaP}_{\mathrm{a}}+\mathrm{MeP}_{\mathrm{a}}+\mathrm{BP}_{\mathrm{a}}\right)$ and the annual community growth efficiency $\left(\mathrm{CGE}_{\mathrm{a}}=\right.$ $\mathrm{CP}_{\mathrm{a}} /\left[\mathrm{CP}_{\mathrm{a}}+\mathrm{BCR}_{\mathrm{a}}\right]$ ) were calculated. $\mathrm{BP}$ represented between 26 and $46 \%$ (average $36 \%$ ) and between 53 and $69 \%$ (average $61 \%$ ) of the $\mathrm{CP}_{\mathrm{a}}$ at Stns A and $\mathrm{C}$, respectively. $\mathrm{CGE}_{\mathrm{a}}$ represented the distribution of carbon into anabolic and catabolic pathways at the community level, and ranged from 44 to $58 \%$ (average $51 \%$ ) and 77 to $82 \%$ (average $79 \%$ ) at Stns A and C, respectively.

\section{Bacterial growth efficiency}

Fig. 5 represents $\mathrm{BGE}_{\mathrm{a}}$ calculated from $\mathrm{BP}_{\mathrm{a}}$ measurements and incremental increases (from 0 to $100 \%$ ) in
$\mathrm{BCR}_{\mathrm{a}}$. Mean BGE $\mathrm{a}$ was $0.49 \pm 0.21$ and $0.83 \pm 0.09$ at Stns $A$ and $C$, respectively. Using a more realistic bracket (from 20 to $80 \%$ of the $\mathrm{BCR}_{\mathrm{a}}$ ), mean $\mathrm{BGE}_{\mathrm{a}}$ represented $0.44 \pm 0.11$ and $0.83 \pm 0.06$ at Stns $A$ and $C_{\text {, }}$ respectively. At both sampling sites, the $\mathrm{BGE}_{\mathrm{a}}$ decreased with increasing $\mathrm{BR}_{\mathrm{a}}$ (Fig. 5). For each increment, the $\mathrm{BGE}_{\mathrm{a}}$ calculated at Stn $\mathrm{C}$ was always higher than that at $\mathrm{Stn} A$ (except when $\mathrm{BR}_{\mathrm{a}}$ represented $0 \%$ of $\mathrm{BCR}_{\mathrm{a}}$ ).

Table 2. Annual production of the main autotrophic and heterotrophic benthic compartments. Annual gross primary production $\left(\mathrm{GPP}_{\mathrm{a}}\right)$, annual benthic community respiration $\left(\mathrm{BCR}_{\mathrm{a}}\right)$, and annual net ecosystem production $\left(\mathrm{NEP}_{\mathrm{a}}=\right.$ $\mathrm{GPP}_{\mathrm{a}}-\mathrm{BCR}_{\mathrm{a}}$ ) were calculated from Hubas \& Davoult (2006). Annual macrofauna production $\left(\mathrm{MaP}_{\mathrm{a}}\right)$ and annual meiofauna production $\left(\mathrm{MeP}_{\mathrm{a}}\right)$ were calculated from Hubas et al. (2006). Annual bacterial production $\left(\mathrm{BP}_{\mathrm{a}}\right)$ was calculated from measurements of this study. Total benthic community production $\left(\mathrm{CP}_{\mathrm{a}}=\right.$ $\mathrm{MaP}_{\mathrm{a}}+\mathrm{MeP}_{\mathrm{a}}+\mathrm{BP}_{\mathrm{a}}$ ) and annual community growth efficiency (in \%; $\mathrm{CGE}_{\mathrm{a}}=$ $\left.\mathrm{CP}_{\mathrm{a}} /\left[\mathrm{CP}_{\mathrm{a}}+\mathrm{BCR}_{\mathrm{a}}\right]\right)$ were also calculated. All production and respiration rates expressed in $\mathrm{g} \mathrm{C} \mathrm{m}^{-2} \mathrm{yr}^{-1}$

\begin{tabular}{|lcccccccc|}
\hline Stn & $\mathrm{GPP}_{\mathrm{a}}$ & $\mathrm{BCR}_{\mathrm{a}}$ & $\mathrm{NEP}_{\mathrm{a}}$ & $\mathrm{MaP}_{\mathrm{a}}$ & $\mathrm{MeP}_{\mathrm{a}}$ & $\mathrm{BP}_{\mathrm{a}}$ & $\mathrm{CP}_{\mathrm{a}}$ & $\mathrm{CGE}_{\mathrm{a}}$ \\
\hline $\mathrm{A}$ & 28.8 & 51.3 & -22.5 & $3.7-22.3$ & $17.9-29.8$ & 18.8 & $40.4-70.9$ & $44-58$ \\
$\mathrm{C}$ & 6.7 & 4.3 & +2.4 & $0.3-1.9$ & $4.3-7.1$ & 10.1 & $14.7-19.1$ & $77-82$ \\
\hline
\end{tabular}




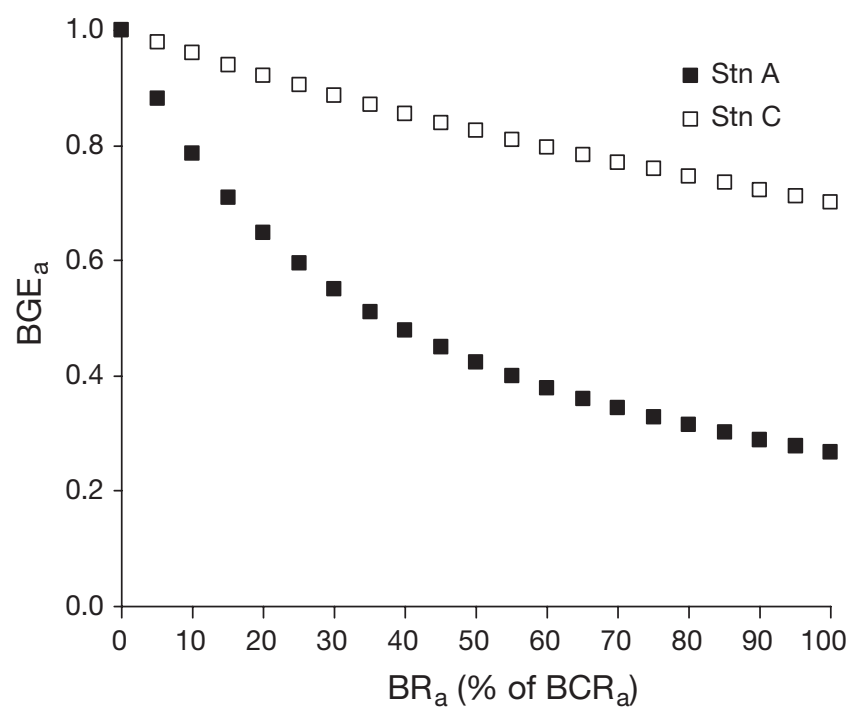

Fig. 5. Annual bacterial growth efficiency $\left(\mathrm{BGE}_{\mathrm{a}}\right)$ at Stns $A$ and $\mathrm{C} . \mathrm{BGE}_{\mathrm{a}}$ was calculated by estimating annual bacterial respiration $\left(\mathrm{BR}_{\mathrm{a}}\right)$ from incremental increases (0 to 100\%) in annual benthic community respiration $\left(\mathrm{BCR}_{\mathrm{a}}\right)$

\section{DISCUSSION}

\section{Temperature influence}

Temperature is recognized to have a significant effect on microbial production in marine habitats. The effect of temperature fluctuation on primary production - particularly on exposed tidal flats - is largely recognized (Admiraal 1977, Rasmussen et al. 1983, Blanchard et al. 1996, Hancke \& Glud 2004). In Roscoff Aber Bay, GPP showed lower-end mesophilic temperature response curves at Stn A (Hubas et al. 2006). Hubas et al. (2006) also showed that GPP was significantly controlled by temperature at Stn C. At these stations, a rise of $10^{\circ} \mathrm{C}$ would increase the GPP 1.6 and 1.4 times, respectively. Moreover, BP is also known to be significantly controlled by temperature changes (White et al. 1991): accounting for changes in temperature generally increases the proportion of variation in BP that can be explained (Cammen 1991, White et al. 1991, Sander \& Kalff 1993).

In the present study, BP was significantly linked to in situ sediment temperature $\left(Q_{10}=2.0\right.$ and 3.8 at Stns $\mathrm{A}$ and $\mathrm{C}$, respectively). Moreover, under experimental conditions, BP showed lower-end mesophilic temperature response curves at $\operatorname{Stn} \mathrm{A}$ (where $T_{\text {opt }}=27.4^{\circ} \mathrm{C}$ ). This indicated that bacterial communities were probably growing best at moderate temperatures and that maximum BP occurred when temperature was close to the summer values. It also appeared that the relation between metabolism and temperature is described more correctly by the cardinal temperature criteria (rather than by an ongoing exponential increase). It is probably the best way to quantify the short-term temperature effect on benthic metabolism. This was previously observed for GPP rates in Roscoff Aber Bay (Hubas et al. 2006) and in similar environments (Blanchard et al. 1996). However, even though the $T_{\text {opt }}$ recorded in the present study (in May 2005) is probably not representative of the entire year, it indicated that bacterial communities are well adapted to their environment, particularly to temperature changes.

In May 2005, BP rates were relatively lower at Stn C than at Stn A and, when compared with their magnitude, highly variable. Thus, even if the optimum was located within the observed range of temperature, it would be difficult to fit the cardinal temperature model properly. However, on an annual scale, it is apparent that BP was closely linked to temperature at both stations. At this scale, fitting a sinusoidal curve to BP would indicate the percentage of the variability explained by a curve that simulates the seasonal variation in temperature (in this study, 89 and $85 \%$ at Stns A and $\mathrm{C}$, respectively). The remaining variability could probably be explained by (1) the daily variation in temperature owing to the day/night and the tidal cycle, and (2) the daily variation in substrate concentration.

\section{Microbial production along a granulometric gradient}

It is recognized that substrate concentration and temperature interact in all bacterial populations, and that this interaction is limiting for heterotrophic BP (Pomeroy \& Wiebe 2001). In the present study, the BP $\left(\right.$ mean $\pm \mathrm{SD}=53.8 \pm 29.8$ and $28.1 \pm 29.6 \mathrm{mg} \mathrm{C} \mathrm{m}^{-2} \mathrm{~d}^{-1}$ at Stns $A$ and $C$, respectively) and specific growth rate $\left(\mathrm{BP}: \mathrm{BB}\right.$ ratio, mean $\pm \mathrm{SD}=2.0 \pm 1.3$ and $2.2 \pm 1.5 \mathrm{~d}^{-1}$ at Stns $A$ and $C$, respectively) were in the same range as $\mathrm{BP}$ and specific growth rates reported in the literature (from 1 to $43200 \mathrm{mgC} \mathrm{m}^{-2} \mathrm{~d}^{-1}$ and 0.005 to $5.5 \mathrm{~d}^{-1}$, respectively; Sander \& Kalff 1993). On an hourly scale (Fig. 2), BP was always less important than the GPP. The BP:GPP ratio was similar at the 2 sampling sites and represented on average $12 \pm 4 \%$ at Stn A and $14 \pm$ $14 \%$ at Stn C. In a wide variety of sites in the open ocean, BP has been reported to be usually 10 to $20 \%$ of the corresponding primary production (Cole et al. 1988, Ducklow 1999, 2000). The ratio was thus within the range previously reported; however, the variability at Stn C was very marked.

Intertidal soft sediments are highly productive, and benthic microalgae generally dominate the primary production in muddy and sandy sediments (McIntyre et al. 1996). According to Hubas \& Davoult (2006), microalgae production represents $88 \%$ of the annual 
primary production in Roscoff Aber Bay. The first objective of this study was to compare the BP, GPP, and $\mathrm{BCR}$ at either end of a granulometric gradient. Preliminary experiments demonstrated that this environmental gradient strongly constrained the dynamics of benthic macrofauna, meiofauna and bacterial communities; however, the activity of benthic organisms (particularly GPP) appeared to be controlled by seasonal temperature variation rather than by this gradient (Hubas et al. 2006). In the present study, BP did not differ significantly between Stns A and C (Mann-Whitney $U$-test, $\mathrm{p}>0.05$ ), whereas both primary production and community respiration differed significantly between these sampling sites (Mann-Whitney $U$-test, $\mathrm{p}<0.01$ ). This is surprising because average organic matter content (loss of weight on ignition at $600^{\circ} \mathrm{C}$ ) at Stns $\mathrm{A}$ and C was 3.0 and $1.1 \%$, respectively (authors' unpubl. results), and because BP is generally well correlated with organic matter content in a wide range of marine sediments (Sander \& Kalff 1993). This correlation is also generally affected by the availability of easily degradable sources of organic carbon (Thingstad 2000). In this study, even though the percentage of labile organic matter was not measured at the 2 sampling sites, the results indicated that the granulometric gradient was a poor predictor of $\mathrm{BP}$, and that $\mathrm{BP}$ was probably controlled by temperature rather than by organic matter concentration.

\section{Role of bacteria in annual benthic community production: a sustainable bacterial development}

With regard to the amount of carbon processed by the heterotrophic community on an annual scale (i.e. the quantity of carbon produced by macrofauna, meiofauna and bacteria + the quantity of carbon respired by the community), the amount of carbon allocated to production varied significantly between the 2 sampling sites (on average, $\mathrm{CGE}_{\mathrm{a}}=51$ and $79 \%$ at Stns $\mathrm{A}$ and $\mathrm{C}$, respectively, Table 2). In a previous study, Hubas \& Davoult (2006) showed that the net ecosystem primary production $\left(\mathrm{NEP}_{\mathrm{a}}\right)$ differed radically between these sampling sites, being highly heterotrophic at Stn A $\left(-22.5 \mathrm{~g} \mathrm{C} \mathrm{m}^{-2} \mathrm{yr}^{-1}\right)$ and poorly autotrophic at Stn C $\left(+2.4 \mathrm{gC} \mathrm{m}^{-2} \mathrm{yr}^{-1}\right)$. It is thus supposed that at the ecosystem level, the net balance between primary production and community respiration is influenced by the allocation of carbon into anabolic and catabolic pathways by the heterotrophic community. The role of bacterial communities in this partitioning was tested in the present study.

As described above, BP did not differ significantly between Stns A and C. However, its contribution to the bulk benthic community production $\left(\mathrm{CP}_{\mathrm{a}}\right)$ was less important at Stn A than at Stn C (on average, 36 and $61 \%$ respectively). Concerning bacterial respiration, it was not possible to measure the fraction of BCR that could be attributed to bacteria. However, we can assume that this fraction is important because (1) the contribution of bacterial respiration to the bulk benthic community respiration is generally considered to be significant when compared to their relative low biomass (Dye 1981, van Es 1982, Schwinghamer et al. 1986, Piepenburg et al. 1995), and (2) the role of the bacterial compartment in community respiration in Roscoff Aber Bay was highlighted by Hubas et al. (2006). Moreover, the BGE is generally low in marine ecosystems and, on average, is close to $30 \%$ in the water column of estuaries (del Giorgio \& Cole 2000). This value is close to the lowest $\mathrm{BGE}_{\mathrm{a}}$ calculated at $\mathrm{Stn}$ A (i.e. $31 \%$, corresponding to a $\mathrm{BR}_{\mathrm{a}}$ representing $80 \%$ of $\mathrm{BCR}_{\mathrm{a}}$ ). If we assume that there is no difference in the distribution of carbon into anabolic and catabolic pathways between the pelagic and benthic compartments, then bacterial respiration should represent the majority of the community respiration.

At Stn $C$, if we consider that $B_{a}$ represented between 20 and $80 \%$ of $\mathrm{BCR}_{\mathrm{a}}$, then $\mathrm{BGE}_{\mathrm{a}}$ ranged between 75 and $92 \%$, which corresponded to very high values of BGE. This indicated that at Stn $C$, the majority of the carbon processed during 1 yr was allocated to the production of new cells. Some uncertainties regarding $\mathrm{BGE}_{\mathrm{a}}$ are associated with the techniques used in this study: (1) the annual BP was probably underestimated because some anaerobic bacteria (which are likely important in intertidal sediments) do not incorporate extracellular thymidine (Tuominen 1995 and references therein), and (2) the annual community respiration was likely underestimated because respiration was measured during low tide and integrated over $24 \mathrm{~h}$, even though it is thought to increase slightly during immersion (Cook et al. 2004).

Nevertheless, despite these uncertainties and although the estimated $\mathrm{BGE}_{\mathrm{a}}$ was variable (coefficient of variation represented up to 43 and $11 \%$ at Stns A and $\mathrm{C}$, respectively), the difference between the 2 sampling sites was significant (Mann-Whitney $U$-test, $\mathrm{p}<$ 0.01 ) regardless of the percentage of the $\mathrm{BCR}_{\mathrm{a}}$ used to estimate the bacterial respiration. The $\mathrm{BGE}_{\mathrm{a}}$ thus increased with increasing median grain size. This indicates that there was a significant difference in the allocation of resource by the bacterial community between Stns A and C.

Although carbon was probably non-limiting, bacterial respiration is probably favoured in sediments in which the concentration of this substrate is non-limiting. Inversely, the production of new cells is probably preferred when carbon concentration is lower, sustaining the development of the community on an annual 
scale. This hypothesis contradicts the general view that, despite its great variability, BGE increases from the open ocean to estuaries (i.e. from $\sim 15$ to $30 \%$, del Giorgio \& Cole 1998, 2000), but it is supported by recent measurements taken from a Wimereux sandy beach (Hubas et al. 2007), assuming that BGE decreases when the sediment is subjected to an input of organic matter.

\section{CONCLUSIONS}

This study suggests that, on an annual scale, BP in the intertidal soft sediment of Roscoff Aber Bay is probably controlled by temperature changes rather than by changes in organic matter concentration. Moreover, when taking into account the production of most of the sediment fauna, annual BP could represent up to $69 \%$ of the total annual secondary production, emphasizing the role of the bacterial compartment in the carbon flow of marine intertidal sediments.

The comparison between 2 sites of different trophic status located at either end of a strong environmental gradient showed that $\mathrm{BGE}_{\mathrm{a}}$ increased with increasing median grain size, indicating that there is a significant difference in the allocation of carbon by the bacterial community between the 2 stations. We hypothesized that, in intertidal sediments, the production of new cells is favoured when the concentration of organic matter is lower, sustaining the development of the community on an annual scale. This hypothesis could be tested with additional measurements and experiments conducted at other sampling sites that encompass a large granulometric gradient.

Stn A presented the most heterotrophic carbon budget and was also characterized by the lowest $\mathrm{BGE}_{\mathrm{a}}$. Because bacterial respiration is likely responsible for the majority of the community respiration, it is supposed that this heterotrophy is mainly supported by the capacity of bacterial communities to shift between anabolic and catabolic pathways.

Acknowledgements. We thank anonymous reviewers for improving an earlier version of our manuscript.

\section{LITERATURE CITED}

Admiraal W (1977) Influence of light and temperature on the growth rate of estuarine benthic diatoms in culture. Mar Biol 39:1-9

Bell RT (1993) Estimating production of heterotrophic bacterioplankton via incorporation of tritiated thymidine. In: Kemp PF, Sherr BF, Sherr EB, Cole JJ (eds) Handbook of methods in aquatic microbial ecology. Lewis Publishers, Boca Raton, FL, p 495-503
Blanchard GF, Guarini JM, Richard P, Gros P, Mornet F (1996) Quantifying the short-term temperature effect on lightsaturated photosynthesis of intertidal microphytobenthos. Mar Ecol Prog Ser 134:309-313

Böttcher ME, Hespenheide B, Llobet-Brossa E, Beardsley C and 6 others (2000) The biogeochemestry, stable isotope geochemistry, and microbial community structure of a temperate intertidal mudflat: an integrated study. Cont Shelf Res 20:1749-1769

Cammen LM (1991) Annual bacterial production in relation to benthic microalgal production and sediment oxygen uptake in an intertidal sandflat and an intertidal mudflat. Mar Ecol Prog Ser 71:13-25

Chauris L (1988) L'anse de l'Aber en Roscoff un ancien marais littoral envahi par la mer. Penn Bed 18:1-11

Chevaldonné P, Godfroy A (1997) Enumeration of microorganisms from deep-sea hydrothermal chimney samples. FEMS Microbiol Lett 146:211-216

Cho BC, Azam F (1990) Biogeochemical significance of bacterial biomass in the ocean's eutrophic zone. Mar Ecol Prog Ser 63:253-259

Cole JJ (1999) Aquatic Microbiology for ecosystem scientists: new and recycled paradigms in ecological microbiology. Ecosystems 2:215-225

Cole JJ, Findlay S, Pace ML (1988) Bacterial production in fresh and saltwater ecosystems: a cross-system overview. Mar Ecol Prog Ser 43:1-10

Cook PLM, Butler ECV, Eyre BD (2004) Carbon and nitrogen cycling on intertidal mudflats of a temperate Australian estuary. I. Benthic metabolism. Mar Ecol Prog Ser 280: 25-38

Danovaro R, Armeni M, Dell'Anno A, Fabiano M, Manini E, Marrale D, Pusceddu A, Vanucci S (2001) Small-scale distribution of bacteria, enzymatic activities and organic matter in coastal sediments. Microb Ecol 42:177-185

del Giorgio PA, Cole JJ (1998) Bacterial growth efficiency in natural aquatic systems. Annu Rev Ecol Syst 29:503-541

del Giorgio PA, Cole JJ (2000) Bacterial energetics and growth efficiency. In: Kirchman DL (ed) Microbial ecology of the oceans. Wiley-Liss, New York, p 289-325

del Giorgio PA, Williams PJ (2005) Respiration in aquatic ecosystems. Oxford University Press, Oxford

Delmas D, Frikha MG, Reymond H, Linley EAS, Collos Y (1992) Long term microbial community dynamics in a coastal marine pond. Mar Microb Food Webs 6:39-54

Ducklow HW (1999) The bacterial content of the ocean euphotic zone. FEMS Microbiol Ecol 30:1-10

Ducklow HW (2000) Bacterial production and biomass in the oceans. In: Kirchman DL (ed) Microbial ecology of the oceans. Wiley-Liss, New York, p 85-120

Dye AH (1981) A study of benthic oxygen consumption on exposed sandy beaches. Estuar Coast Shelf Sci 13: $671-680$

Epstein SS (1997) Microbial food webs in marine sediments. II. Seasonal changes in trophic interactions in a sandy tidal flat community. Microb Ecol 34:199-209

Fenchel T (1978) The ecology of micro- and meiobenthos. Annu Rev Ecol Syst 9:99-121

Fuhrman JA, Azam F (1982) Thymidine incorporation as a measure of heterotrophic bacterioplankton production in marine surface waters: evaluation and field results. Mar Biol 66:109-120

Garet MJ, Moriarty DJW (1996) Acid extraction of tritium label from bacterial DNA in clay sediment. J Microbiol Methods 25:1-4

Gerlach SA (1971) On the importance of marine meiofauna for benthos communities. Oecologia 6:176-190 
Goñi-Urriza M, de Montaudouin X, Guyoneaud R, Bachelet G, de Wit R (1999) Effect of macrofaunal bioturbation on bacterial distribution in marine sandy sediments, with spetial reference to sulfure-oxidising bacteria. J Sea Res 41:269-279

Hancke K, Glud RN (2004) Temperature effects on respiration and photosynthesis in three diatom-dominated benthic communities. Aquat Microb Ecol 37:265-281

Hubas C, Davoult D (2006) Does seasonal proliferation of Enteromorpha sp. affect the annual benthic metabolism of a small macrotidal estuary? (Roscoff Aber Bay, France). Estuar Coast Shelf Sci 70:287-296

Hubas C, Davoult D, Cariou T, Artigas LF (2006) Factors controlling benthic metabolism during low tide along a granulometric gradient in an intertidal bay (Roscoff Aber Bay, France). Mar Ecol Prog Ser 316:53-68

Hubas C, Lamy D, Artigas LF, Davoult D (2007) Seasonal varirability of intertidal bacterial metabolism and growth efficiency in an exposed sandy beach during low tide. Mar Biol 151:41-52

Isaksen MF, Jørgensen BB (1996) Adaptation of psychrophilic and psychrotrophic sulfate-reducing bacteria to permanently cold marine sediments. Appl Environ Microbiol 62: 408-414

Jahnke RA, Craven DB (1995) Quantifying the role of heterotrophic bacteria in the carbon cycle: a need for respiration rate measurements. Limnol Oceanogr 40:436-441

Koop K, Griffiths CL (1982) The relative significance of bacteria, meio- and macrofauna on an exposed sandy beach. Mar Biol 66:295-300

Lee SH, Fuhrman L (1987) Relationship between biovolume and biomass of naturally derived marine bacterioplankton. Appl Environ Microbiol 53:1298-1303

Lorenzen CJ (1966) A method for the continuous measurment of in vivo chlorophyll concentration. Deep-Sea Res 13: 223-227

Lucas F, Meziane T, Bertru G, Retière C (1996) Bactéries du sédiment: extraction et distribution sur un estran (Bais du Mont-Saint-Michel). CR Acad Sci Paris 319:537-542

McIntyre HL, Geider RJ, Miller DC (1996) Microphytobenthos: the ecological role of the 'secret garden' of unvegeted, shallow-water marine habitats. I. Distribution, abundance and primary production. Estuaries 19:186-201

Middelburg JJ, Barranguet C, Boschker HTS, Herman PMJ, Moens T, Heip CHR (2000) The fate of intertidal microphytobenthos carbon: an in situ ${ }^{13} \mathrm{C}$-labeling study. Limnol Oceanogr 45:1224-1234

Migné A, Davoult D, Spilmont N, Menu D, Boucher G, Gattuso JP, Rybarczyk H (2002) A closed-chamber $\mathrm{CO}_{2}$-flux method for estimating intertidal primary production and respiration under emersed conditions. Mar Biol 140: 865-869

Migné A, Spilmont N, Davoult D (2004) In situ measurements of benthic primary production during emersion: seasonal variations and annual production in the Bay of Somme (eastern English Channel, France). Cont Shelf Res 24: 1437-1449

Moriarty DJW (1986) Measurement of bacterial growth rates and production of biomass in aquatic environments. In:

Editorial responsibility: Howard Browman (Associate Editorin-Chief), Storebø, Norway
Grigorova R, Norris JR (eds) Methods in microbiology. Academic Press, San Diego, CA, p 211-234

Piepenburg D, Blackburn TH, von Dorrien CF, Gutt J and 6 others (1995) Partitioning of benthic community respiration in the Arctic (northwestern Barents Sea). Mar Ecol Prog Ser 118:199-213

Pomeroy LR, Wiebe WJ (2001) Temperature and substrates as interactive limiting factors for marine heterotrophic bacteria. Aquat Microb Ecol 23:187-204

Porter KG, Feig YS (1980) The use of DAPI for identifying and counting aquatic microflora. Limnol Oceanogr 25:943-948

Raffaelli D, Hawkins CM (1999) Intertidal ecology. Kluwer Academic, Dordrecht

Raghukumar C, Loka Bharathi PA, Ansari ZA, Nair S and 5 others (2001) Bacterial standing stock, meiofauna and sediment-nutrient characteristics: indicators of benthic disturbance in the Central Indian Bassin. Deep-Sea Res II 48:3381-3399

Rasmussen MB, Henriksen K, Jensen A (1983) Possible causes of temporal fluctuations in primary production of the microphytobenthos in the Danish Wadden Sea. Mar Biol 73:109-114

Roland F, Cole JJ (1999) Regulation of bacterial growth efficiency in a large turbid estuary. Aquat Microb Ecol 20: 31-38

Sander BC, Kalff J (1993) Factors controlling bacterial production in marine and freshwater sediments. Microb Ecol 26:79-99

Schwinghamer P, Hargrave B, Peer D, Hawkins CM (1986) Partitioning of production and respiration among size groups of organisms in an intertidal benthic community. Mar Ecol Prog Ser 31:131-142

Spilmont N, Davoult D, Migné A (2006) Benthic primary production during emersion: in situ measurements and potential primary production in the Seine Estuary (English Channel, France). Mar Pollut Bull 53:49-55

Steele JH (1974) The stucture of marine ecosystems. Harvard University Press, Cambridge, MA

Strickland JDH, Parsons TR (1972) A practical hanbook of seawater analysis. Bull Fish Res Board Can 167

Thingstad TF (2000) Control of bacterial growth in idealized food webs. In: Kirchman DL (ed) Microbial ecology of the oceans. Wiley-Liss, New York, p 229-260

Tuominen L (1995) Comparison of leucine uptake methods and a thymidine incorporation method for mesuring bacterial activity in sediment. J Microbiol Methods 24: $125-134$

van Es FB (1982) Community metabolism of intertidal flats in the Ems-Dollard Estuary. Mar Biol 66:95-108

Webb WL, Newton M, Starr D (1974) Carbon dioxide exchange of Alnus rubra: a mathematical model. Oecologia 17:281-291

White PA, Kalff J, Rasmussen JB, Gasol JM (1991) The effect of temperature and algal biomass on bacterial production and specific growth rate in freshwater and marine habitats. Microb Ecol 21:99-118

Yentsch CS, Menzel DW (1963) A method for the determination of phytoplankton chlorophyll and phaeophytin by fluorescence. Deep-Sea Res 10:221-231

Submitted: August 25, 2006; Accepted: March 4, 2007 Proofs received from author(s): August 14, 2007 